\title{
Social and Environmental Impacts on Rural Communities Residing Near the Industrial Complex of São Luís Island, State of Maranhão, Brazil
}

\author{
Tatiana Cristina Santos de Castro ${ }^{1}$, Antonio Carlos Leal de Castro ${ }^{1}$, Leonardo Silva Soares ${ }^{1}$, Marcelo Henrique \\ Lopes Silva ${ }^{1}$, Helen Roberta Silva Ferreira ${ }^{1}$, James Werllen de Jesus Azevedo ${ }^{1}$ \& Victor Lamarão de França ${ }^{1}$ \\ ${ }^{1}$ Department of Oceanography and Limnology, Federal University of Maranhão, São Luís, Maranhão, Brazil \\ Correspondence: Tatiana Cristina Santos de Castro, Departamento de Oceanografia e Limnologia, Universidade \\ Federal do Maranhão, Avenida dos Portugueses - Campus do Bacanga - 1966, CEP: 65080-805. São Luís, \\ Maranhão. Brasil. Tel: 55-98-3272-8563. E-mail: tatiana.castro21@hotmail.com
}

Received: January 6, 2017

doi:10.5539/jsd.v10n2p249
Accepted: February 2, 2017 Online Published: March 30, 2017

URL: https://doi.org/10.5539/jsd.v10n2p249

\begin{abstract}
The aim of the present study was to analyze the major social and environmental implications of the presence of the industrial district of the city of São Luís (Brazil) over a span of 30 years. The district was established in the 1980s to receive industrial enterprises of the Grande Carajás Program, which led to the installation of a massive support infrastructure. Industrial activities have contributed substantially to rapid, definitive, irreversible changes to the way of life of the population residing near the district and have gradually altered the spatial organization of the area, with consequent harm to the natural landscape. Both the perceptions of the local population and data obtained using geotechnological tools offer evidence of the main changes having occurred and factors associated with such changes. Mangrove degradation and the loss of both natural and secondary vegetal cover were the most significant changes in the time interval studied. The main factors associated with environmental harm are industrial activities, the mineral extraction of sand and disorganized land occupation.
\end{abstract}

Keywords: São Luís Industrial District, Grande Carajás Program, economic development, socio-environmental implications

\section{Introduction}

The industrial district of the city of São Luís (northeastern Brazil) was established in the 1980s to receive enterprises of the Grande Carajás Program, the aim of which was to exploit the mineral reserves of the Carajás Hills located in the southeastern portion of the neighboring state of Pará on an industrial scale for the international market. The Grande Carajás Program is considered the framework of a unique industrial process and is undoubtedly a historical benchmark that symbolizes social, economic, environmental and cultural changes in the population that resides in the surrounding area. The concretization of the program was only possible due to a set of actions on the part of the federal government, such as the creation of institutional apparatuses, legal devices as well as fiscal and tax incentive policies aimed at permitting the exploitation of mineral, forest, agricultural and industrial production in Maranhão and neighboring states, establishing a development model with the implantation of infrastructure at high environmental cost (Sant'ana-Junior, 1999).

The Carajás program and other developmental initiatives led to the implantation of a massive support infrastructure network in the state of Maranhão, with the construction of the Serra de Carajás-São Luís railway that links the mines in Carajás in the state of Pará to Madeira Port in the city of São Luís in Maranhão, the expansion of the Itaqui Port in São Luís and the creation of the São Luís industrial district. The region chosen to house the industrial district was occupied by the traditional rural communities of Tibiri-Pedrinhas and Itaqui-Bacanga. In 1974, when the topographic survey and basic executive engineering projects were initiated, Boqueirão and Anjo da Guarda near the Itaqui Port were the first communities to be contacted with regard to the implantation of large industrial projects (Gistelinck, 1988). After negotiations with the local population, the expropriation phase of the industrial district began, involving the relocation of the communities and the installation of large industrial plants. With the construction of the Ponta da Madeira terminal, the fishing community of Boqueirão was relocated to lots established by the Vale do Rio Doce Company in the 
neighborhood of Alto da Esperança on the banks of the Bacanga River.

The presence of enterprises in rural areas on the island of São Luis contributed substantially to rapid, definitive, irreversible changes to the way of life of local populations and gradually altered the spatial organization of the area. Socio-environmental conflicts arose due to the dynamics of interests, leading to constant land disputes (Nunes and Garcia, 2012). According to Gonçalves (2005), the investigation into contemporary processes that attribute meaning to transformations in the eastern Amazon reveals land occupation processes that are marked by a regional dynamic that involves different actors and conflicting forms of land appropriation. Land disputes, constant changes to the natural landscape, pollution and environment degradation contribute to the tension regarding the São Luís industrial district.

The aim of the present study was to investigate the main social and environmental issues in the industrial district of the city of São Luís, Brazil, using geo-technological tools to highlight the dynamics of disturbances to the natural landscape in a 30-year period.

\section{Material and Methods}

The industrial district of São Luís was created through State Decree ${ }^{\circ} 7.632 / 80$ and is located in the western portion of the city of São Luís, state capital of Maranhão, Brazil. The district occupies an area of 18,861 hectares, corresponding to $22.5 \%$ of the total area of the city (Figure 1). Diverse large, small and medium-size enterprises are found in the district, along with communities established in the area before the implantation of the industrial projects.

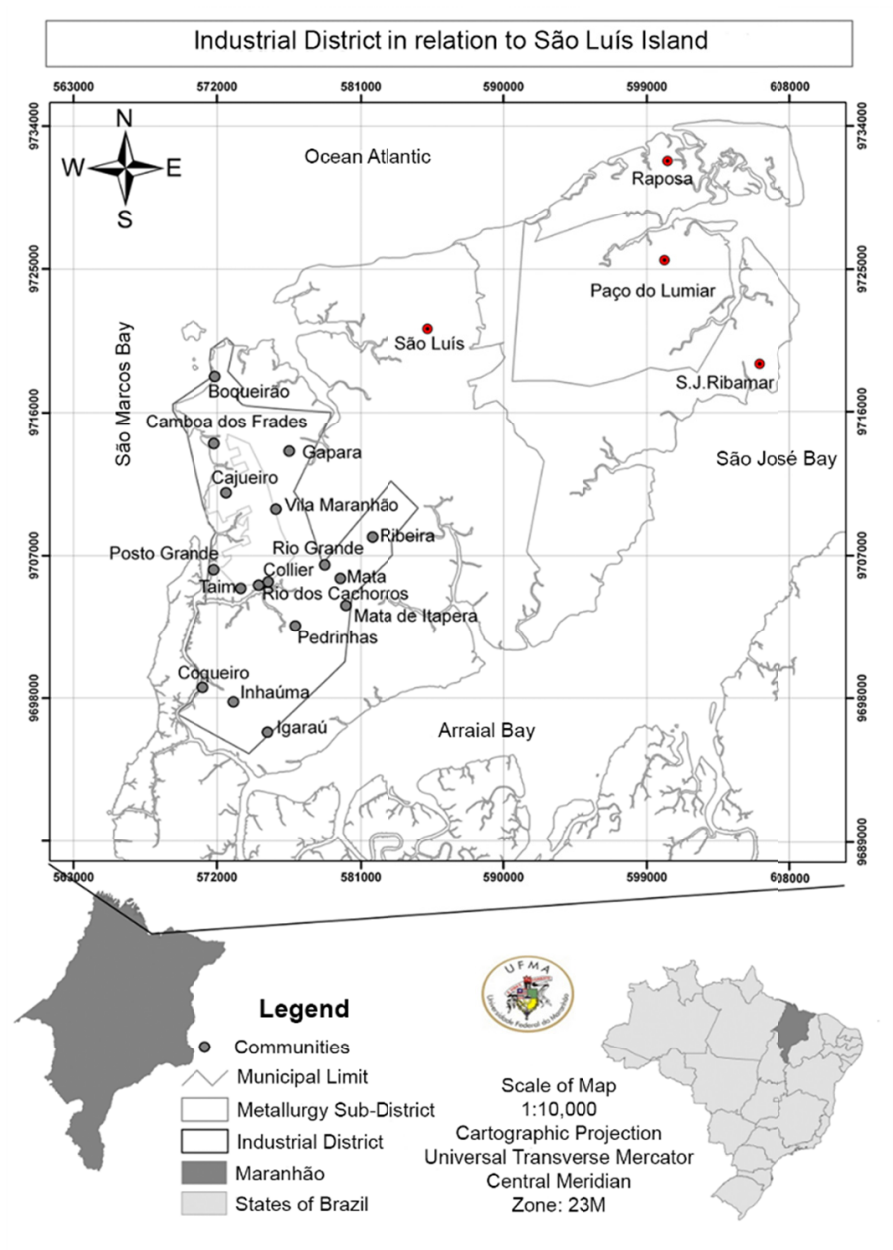

Figure 1. Map of São Luís Island highlighting industrial district

The analysis of the social and environmental implications was performed based on the perceptions of the local population regarding the main changes having occurring in the 30 -year period and the use of geo-technologies (Geographic Information System and Global Positioning System) as well as aerial and satellite images of the 
study area. Environmental changes in the landscape were identified with the creation of spatiotemporal maps of land use, vegetal cover, permanent preservation areas and the hydrographic network. The SPRING software program (version 5.1), Garmin extrex global positioning system, satellite images (LANDSAT 5TM, orbit/point: 220/062; passing dates: June 2, 1984 and April 2, 2010; bands 5, 4 and 3) and aerial photographs from 2012 were used for the analysis.

The socioeconomic characterization of the surrounding communities was based on demographic census data from the Brazilian Institute of Geography and Statistics (IBGE, 2010) as well as shapefile archives of the digital municipal fabric with the spatial delimitation of census sectors. The census sectors within the São Luís industrial district were extracted by overlaying the spatial outline of the district on the IBGE municipal digital fabric. Three information classes were considered in the present study: 1) homes (permanent private homes, type of home, number of residents per home and connections to the water, sewage and electricity systems); 2) household income; and 3) individuals (resident population and literacy). Literacy was determined based on the literacy rate indicator used in IBGE surveys. In the present study, literacy was defined as the ability to read and write a simple note at the age of 15 years or older.

The characterization of environmental perceptions was determined through the administration of a semi-structured questionnaire with open-ended and closed-ended questions as well as individual open-ended interviews registered with the aid of a voice recorder between July and October 2013. The individuals received clarifications regarding the objectives and methods proposed for the acquisition of the data, were assured of access to the information and anonymity and were informed of the right to refuse to participate in the study. Those who agreed to participate signed a statement informed consent. The criterion established was a minimum of 30 years as a resident of the area, independently of gender and schooling.

According to Johansson and Isgren (2017), visualizing the past, present and future through participatory art in combination with conventional methods, such as focus group discussions, interviews and observations helps understand changing land use (e.g., its directionality, drivers and impacts) from a landscape and livelihood perspective.

he "snowball" method was employed during the administration of the questionnaires, which consists of the indication of respondents by other members of the community. Individuals were interviewed until reaching high levels of informational consistency, which was when the sample size was considered adequate (Bailey, 2008). Field campaigns in the study area were also conducted to record the current elements and conditions of the landscape.

The thematic maps generated refer to land use/vegetal cover (1984 and 2010), the hydrographic network (1980 and 2012) and Permanent Preservation Areas (1984 and 2012). The maps were created following the establishment of the databank in an environment of the Geographic Information System, using the Universal Transverse Mercator (UTM) and DATUM SIRGAS 2000. The SPRING software program (version 5.1) was used for the construction of the databank and maps. Land use/vegetal cover was mapped on a scale of 1:50,000 and spanned a period of 26 years (1984 to 2010), with the visual interpretation of LANDSAT 5 TM images composed in bands 5, 4 and 3 (RGB). The hydrographic network maps were constructed based on the digital vectorization of geographic maps from 1980 on a scale of 1:10,000 and the vectorization of aerial photographs from 2012 with a spatial resolution of 1 meter. Field observations were necessary to confirm the existence of the mapped hydrographic network, especially in 2012. Permanent Preservation Areas were mapped in steps, considering Federal Law $n^{\circ} 12.651 / 2012$ and CONAMA Resolution $n^{\circ} 303 / 2002$, which stipulate the parameters, definitions and limits of this category of protected area.

The hydrographic network was mapped beginning with the digital vectorization of geographic maps from 1980 and aerial photos from 2012. Next, a buffer zone was generated out to 30 meters from the banks of the channels of the rivers and streams and 50 meters from the initial drainage points (lakes or springs) for the hydrographic networks generated in the previous step. The entire extension of the mangrove vegetation was then represented based on the visual interpretation of the geographic maps from 1980, aerial photos from 2012 and LANDSAT 5 TM satellite images.

\section{Results and Discussion}

\subsection{Socioeconomic Characterization of the Population}

According to the Brazilian Institute of Geography and Statistics (IBGE, 2010), the industrial district of São Luís has 97 census sectors, $40 \%$ of which are in rural areas and $60 \%$ of which are in urban areas (Figure 2), where 22,592 permanent private homes designed exclusively for habitation are found. Regarding the typology of these 
homes, $99 \%$ are individual houses, $0.5 \%$ are groups of houses and $0.5 \%$ are apartments.

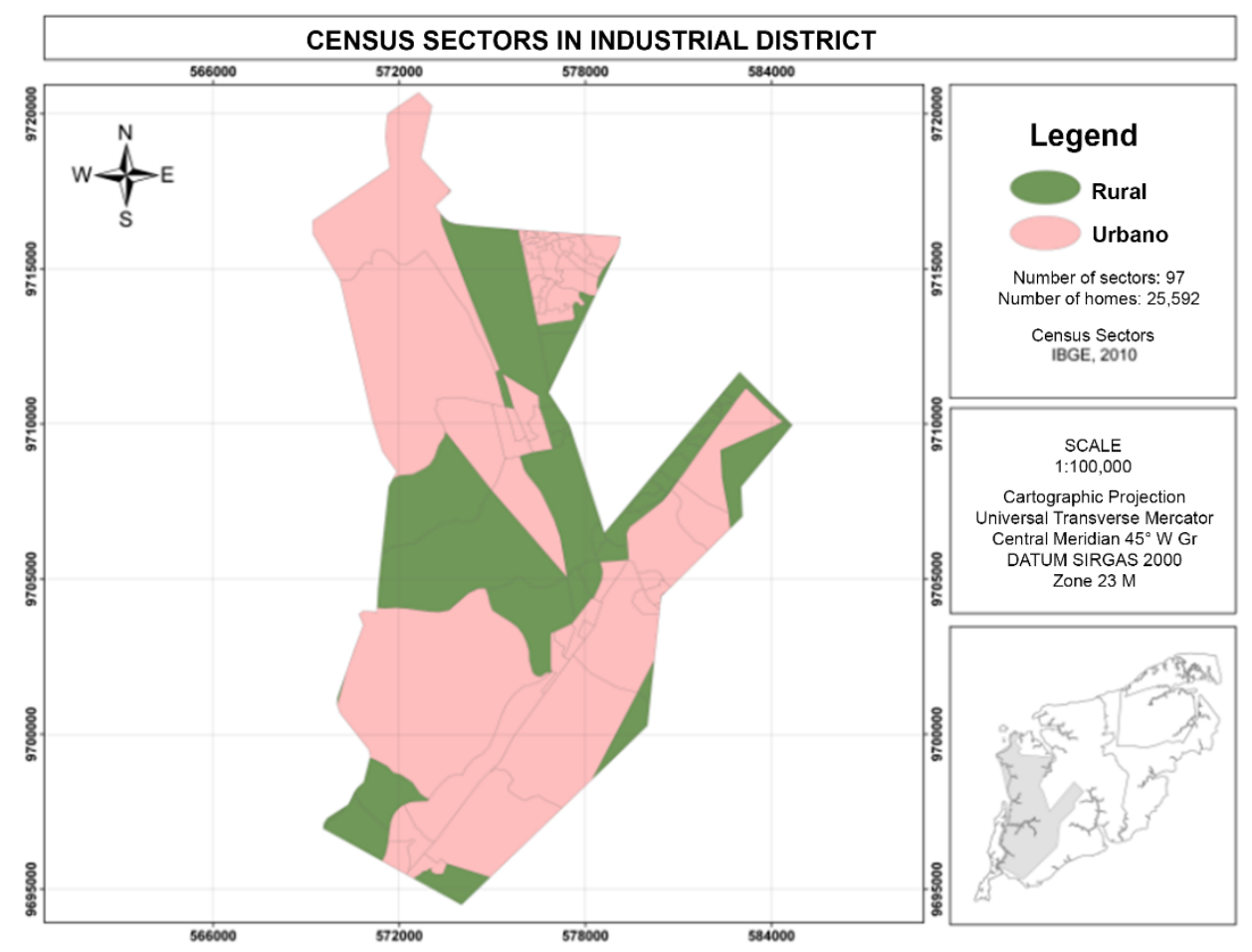

Figure 2. Census sectors in industrial district of São Luís, Maranhão - Brasil

The illiteracy rate is $78 \%$, which is considered low and below the national rate of $91.7 \%$ (BRASIL, 2014). Household income - defined as the sum of all incomes of all residents in the home - in the industrial district was less than or equal to the Brazilian monthly minimum wage (BMMW) in $78 \%$ of the homes, up to two times the BMMW in $19 \%$, up to three times the BMMW in $2 \%$ and higher than three times the BMMW in only $1 \%$ of homes.

Forty-eight percent of the homes have piped water connected to the public water supply through the Maranhão Water and Sewage Company; $37 \%$ use artesian well water (either private or community) and $15 \%$ have other sources, such as a water hole or delivery from a tanker truck. Seventy-six percent of homes are connect to the public sewage system, mainly those located in urban areas (60\% of the district); $19 \%$ have septic tanks and $5 \%$ have other forms of sewage disposal, such as discharge into rivers, streams and open-air ditches.

Sixty-four percent of the homes have their trash picked up regularly by the municipal authority; the residents of $26 \%$ of the homes burn their trash; the residents of $9 \%$ of the homes bury trash on their property and the destiny of the trash is uncertain in $1 \%$ of the homes, possibly dumped in empty lots or discharged into rivers and streams. Figure 3 displays the sanitation conditions of the study area. 


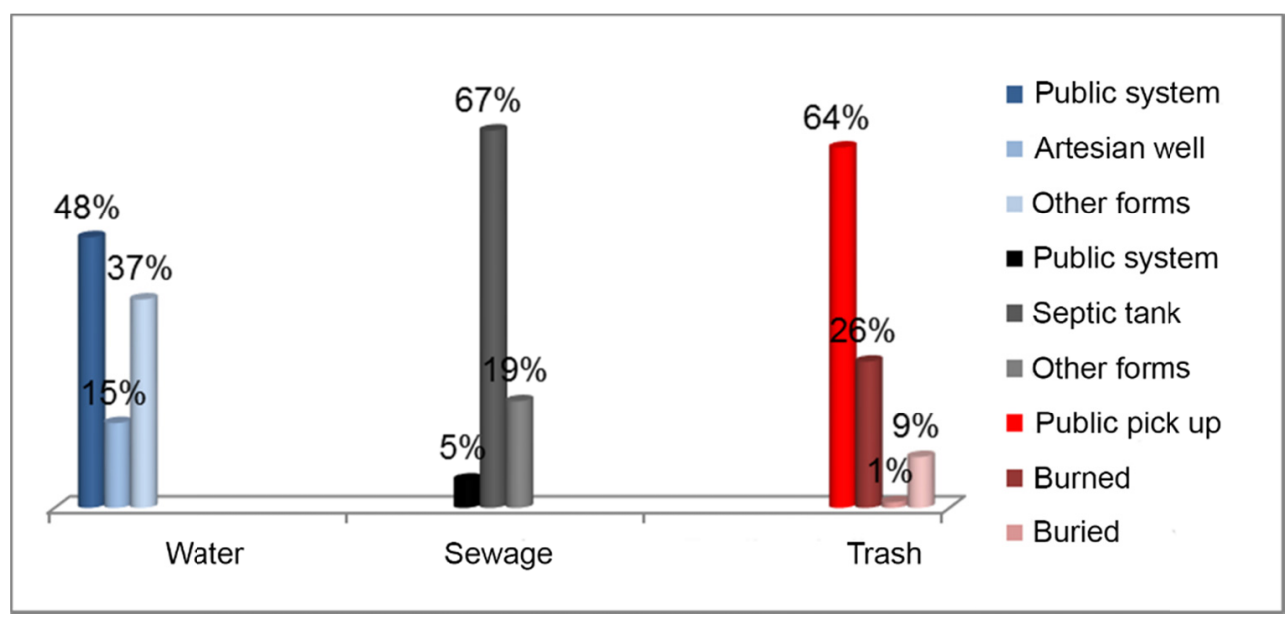

Figure 3. Sanitation conditions in industrial district

Source: Demographic census (IBGE, 2010)

Environmental perceptions were associated with environmental impacts, especially changes to the natural landscape and the factors related to such changes. Among a total of 126 informants, $86 \%$ perceived some type of environmental impact (positive and/or negative) in the region. Among these individuals, $85 \%$ attributed the impacts to the industrial enterprises installed in the area, $13 \%$ offered no opinion and $2 \%$ did not attribute the impacts to the industries.

The most common positive impacts cited were jobs and income $(42.8 \%)$, the development of local commerce $(19.8 \%)$ and improvements in infrastructure in the region (11.9\%). The most common negative impacts cited were the loss of vegetal cover (48.4\%), the removal of mangrove vegetation $(23.0 \%)$, air pollution $(57.9 \%)$ and land use conflicts $(53.9 \%)$.

Impacts produced by large projects bring changes to the population structure, economy, territorial organization, political framework and culture of the local population (Freitas and Oliveira, 2012). On the other hand, ecosystem services in areas around urban settings can be vital to the livability and sustainability of cities and such services are not merely a natural incidental gift, but the complex outcome of coevolving social, political and economic processes as well as social and institutional struggles (Depietri et al., 2016).

According to Sant'Ana Júnior and Silva (2009), conflicts regarding the possession and control of land in the region of São Luís are frequent and threats of displacing the local populations began with the installation of the first heavy industries in the mid 1980s. Likewise, Sant'Ana Júnior and Alves (2010) report threats of the displacement of the community of Camboa dos Frades and the extinction of the community Vila Madureira with the installation of the Itaqui Thermoelectric Plant in the industrial district of São Luís.

The negative impact of vegetal loss refers to the loss of native vegetation of marsh environments, comprising the buriti palm (Mauritia flexuosa) and juçara palm (Euterpe sp.), as well as the loss of mangrove vegetation, such as the white mangrove (Laguncularia racemosa), red mangrove (Rhizophora mangle) and siriúba (Avicennia sp.). Reductions in vegetation on terra firma, such as secondary vegetation in different successional strata, were also observed. In the perception of the informants, degradation of the vegetation is the greatest interference in the natural landscape of the region. Approximately $70 \%$ of the interviewees considered this to be the greatest environmental harm in the area in the 30 -year period, whereas $30 \%$ reported the filling in of bodies of water with earth as the main negative impact on the natural landscape, causing changes in the local watersheds as well as the disappearance of strips of protection alongside these channels, which is an environment considered to be a Permanent Preservation Area.

In terms of air pollution, records monitored by the State of Maranhão Secretary of Industry and Commerce show that air quality in the industrial district of São Luís ranges from good to fair, depending on the location. Areas located in the central and southeastern portions have the capacity to receive atmospheric emissions and maintain a good air quality index, whereas the absorption capacity in the northern, northeastern and southeastern portions is already at the saturation point and the air quality index is categorized as fair.

The data from the Geographic Information System tools demonstrated concordant aspects with the 
environmental perceptions of the informants with regard to the spatiotemporal mapping of land use and vegetal cover in the industrial district. Table 1 lists the main thematic classes identified in the area investigated.

Table 1. Thematic classes identified in spatiotemporal mapping of land use and vegetal cover

\begin{tabular}{ll}
\hline \multicolumn{1}{c}{ Classes } & \multicolumn{1}{c}{ Description } \\
\hline Salt marshes & Areas deprived of vascular vegetation, with salty soils subjected to tidal \\
& action \\
Bodies of water & Natural courses of water, lakes, ponds, estuarine channels and bays \\
Mangroves & Coastal region with ocean influence and mangrove vegetation subjected to \\
& tidal action \\
Secondary vegetation & Areas of vegetal cover resulting from natural regeneration process or \\
& environmental recovery in different successional strata \\
Developed areas & Impermeable areas deprived of vegetal cover, where economic activities \\
& and/or human communities are established \\
\hline
\end{tabular}

The main changes to the natural landscape in the São Luis industrial district predominantly regard vegetal (native, secondary and mangrove) loss. In a span of 26 years (1984 to 2010), terra firma vegetal cover was reduced by 4432.9 hectares. In 1984, vegetation occupied 10,693.9 hectares, corresponding to $56 \%$ of the district. In 2010 , vegetation occupied 6261.0 hectares, corresponding to $33 \%$ of the district. The loss of this vegetation does not include mangroves, which had 489.7 ha of its areas degraded in this timeframe. The degradation of vegetation in the region is directly related to the expansion of developed areas, characterized by industrial occupation, mineral extraction (sand) activities, the construction and expansion of ports and railways, and the occupation of land by rural and semi-urbanized communities (Figure 4).

Developed areas occupied 3684.1 hectares in 1984, corresponding to $19 \%$ of the district. In 2010 , these areas occupied 8605.8 hectares, which corresponds to $45 \%$ of the district. The expansion of developed areas occurred in a more representative manner in the northern sector, where occupation was predominantly due to the Itaqui Port Complex, the southern sector, with the establishment of industrial activities and a small group of residential communities, and the eastern sector, with the predominance of numerous semi-urbanized communities. Developed areas are also found throughout the entire length of the BR-135 roadway southeast to southwest as well as the north-to-south branch of the roadway. These areas are home to commercial establishments, small and medium-size industries as well as land uses and occupation by the resident population near the industries.

The western portion of the district faces São Marcos Bay and maintains good mangrove cover associated with salt marshes, which occupied 36.0 hectares in 1984, with a slight increase (approximately 39.0 hectares) in area in 2010 , representing $1 \%$ in the time interval studied (Table 2). Therefore, salt marshes proved to be less impacted by human activities in comparison to the other compartments of the landscape in the industrial district. 


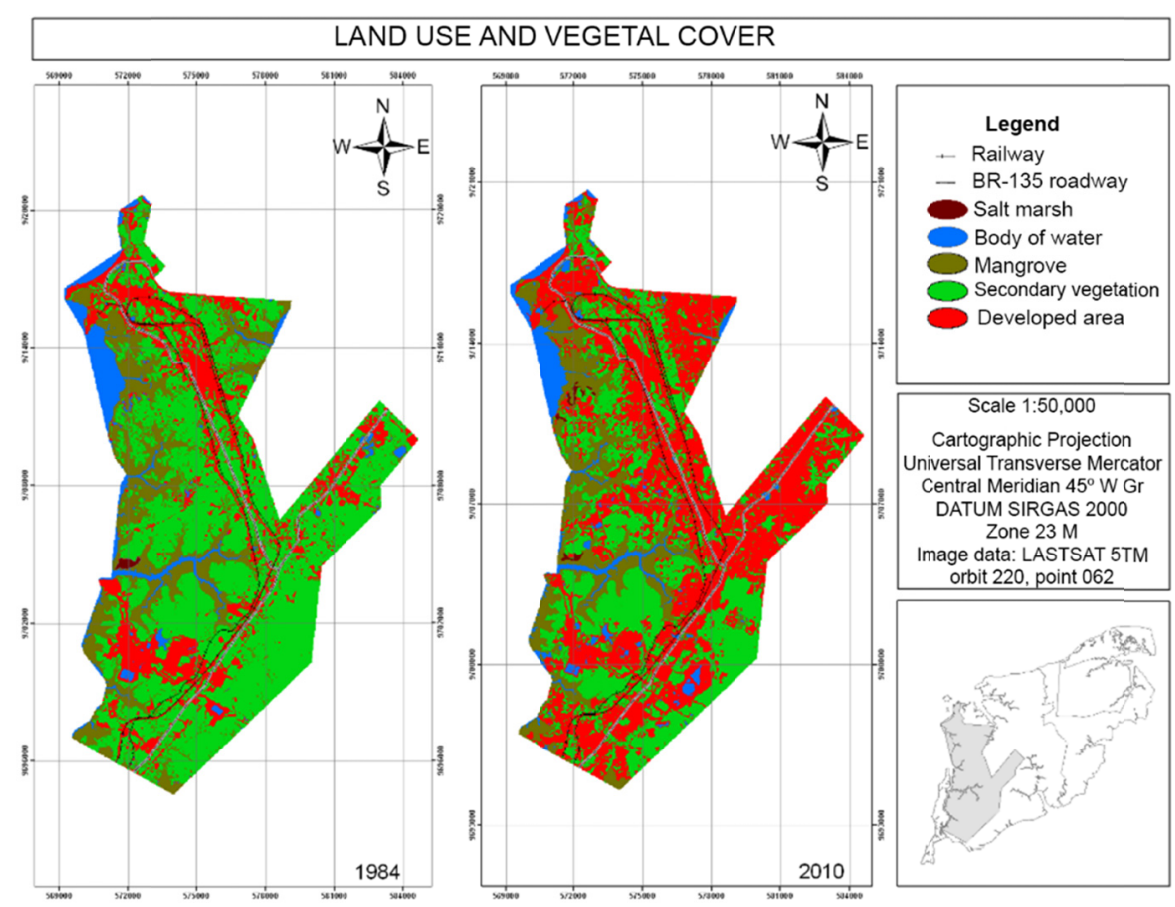

Figure 4. Spatiotemporal map (1984 to 2010) of land use and vegetal cover in São Luís industrial district

Table 2. Classes of land use and vegetal cover in 1984 and 2010

\begin{tabular}{lcccc}
\hline \multicolumn{1}{c}{ Classes } & \multicolumn{1}{c}{$\mathbf{1 9 8 4}$} & \multicolumn{2}{c}{$\mathbf{2 0 1 0}$} \\
\hline & Area (ha) & \% & Area (ha) & \% \\
Salt marshes & 36.00 & 1 & 39.00 & 1 \\
Bodies of water & 1063.34 & 6 & 1049.49 & 6 \\
Mangroves & 3383.55 & 18 & 2893.77 & 15 \\
Secondary vegetation & $10,693.98$ & 56 & 6261.03 & 33 \\
Developed areas & 3684.13 & 19 & 8605.87 & 45 \\
\hline Total & $\mathbf{1 8 , 8 6 1 . 0 0}$ & $\mathbf{1 0 0}$ & $\mathbf{1 8 , 8 6 1 . 0 0}$ & $\mathbf{1 0 0}$ \\
\hline
\end{tabular}

The spatiotemporal mapping of Permanent Preservation Areas (Figure 5) in a 32-year period (1980 to 2012) enabled the identification and quantification of mangroves, springs and the banks of rivers/streams. These classes are established by Federal Law n ${ }^{\circ} 12.651 / 12$, which addresses the protection of native vegetation. Among Permanent Preservation Areas in the industrial district of São Luís, mangroves underwent the most degradation, occupying 3.937.2 hectares in 1980 and only 2535.5 hectares in 21012, which is a loss of 1437.7 hectares (Figure 5). The degradation of mangroves in the study area alters the landscape and exerts a negative impact on local socioeconomic dynamics, as communities in the surrounding area depend on this environment for the practice of subsistence activities, such as artisanal fishing and clam digging, the products of which are destined either for selling, trading or personal consumption. Protection bands along the banks of rivers and streams (defined as 30 meters from the river bed) constituted 1935.5 hectares in 1980 and dropped to 1468.6 hectares in 2012, corresponding to a loss of 466.7 hectares due to land fill operations and channeling projects. Springs (all initial points of rivers and streams formed by the catchment of surface runoff or the fountainhead of groundwater reserves) totaled 488 and occupied an area of 382.2 hectares (considering a horizontal projection radius of 50 meters) in 1980 and 346 points occupying 271.0 hectares in 2012, which is a $29.1 \%$ reduction (142 springs and 111.22 hectares). 


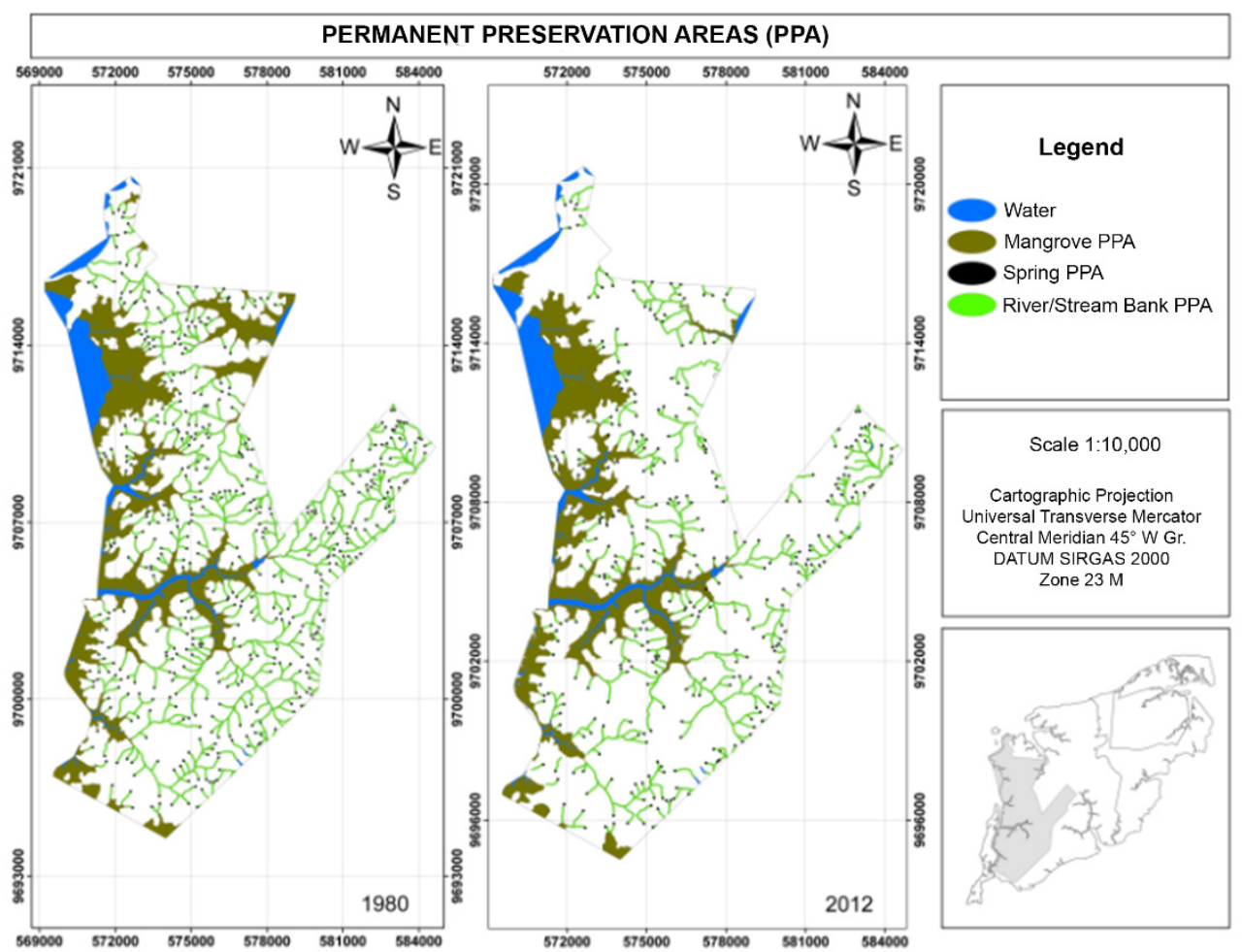

Figure 5. Spatiotemporal map (1980 to 2012) of Permanent Preservation Areas in industrial district of São Luís

The spatiotemporal mapping of the hydrographic network (Figure 2) enabled the quantification of the extension of rivers and streams as well as the hierarchization of the network in the study area. The network totaled an extension of $454.7 \mathrm{~km}$ in 1980 , dropping to $337.4 \mathrm{~km}$ in 2012 . The loss of approximately $117.3 \mathrm{~km}$ was mainly related to the installation of industrial facilities, sand extraction activities and the disorganized occupation of the area, especially in the northern, eastern and southern portions of the industrial district (Figure 7).

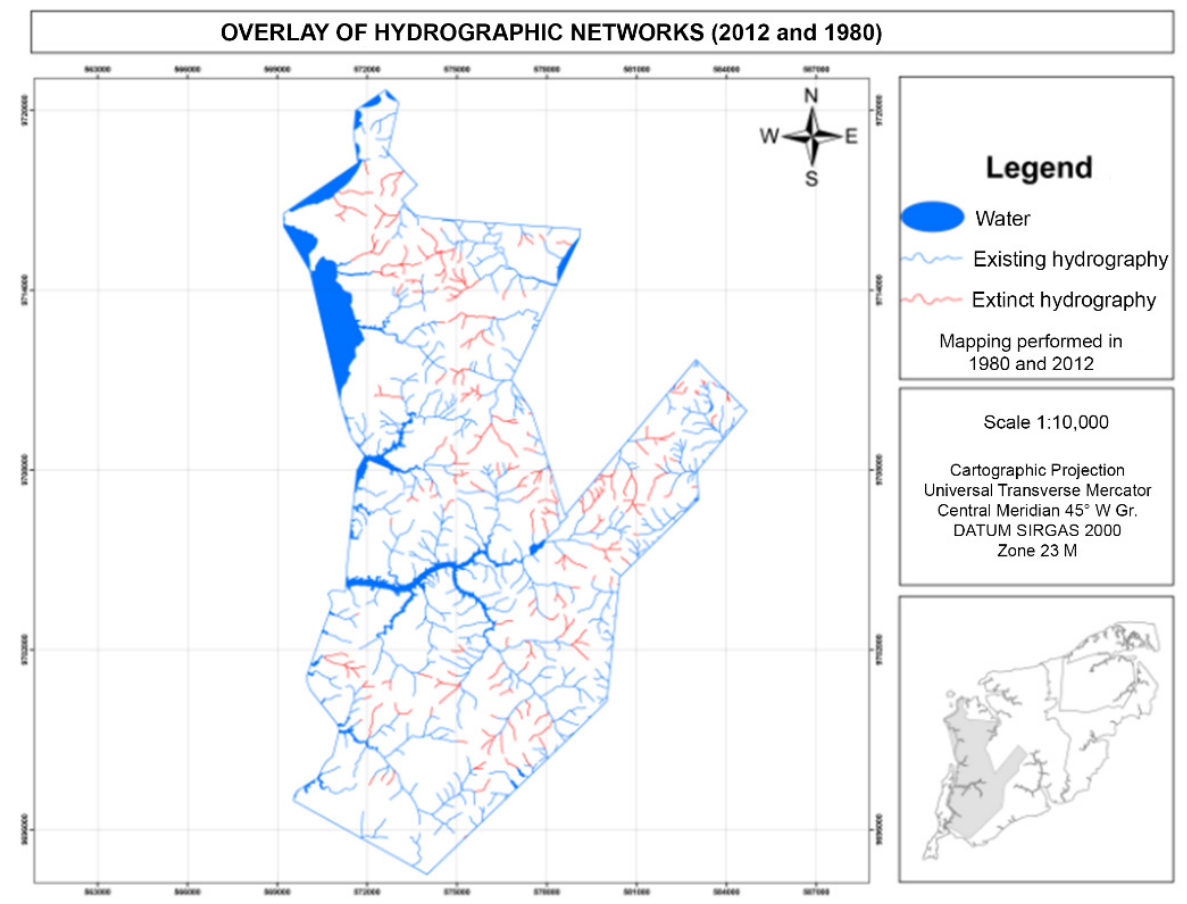

Figure 6. Overlay of hydrographic networks 


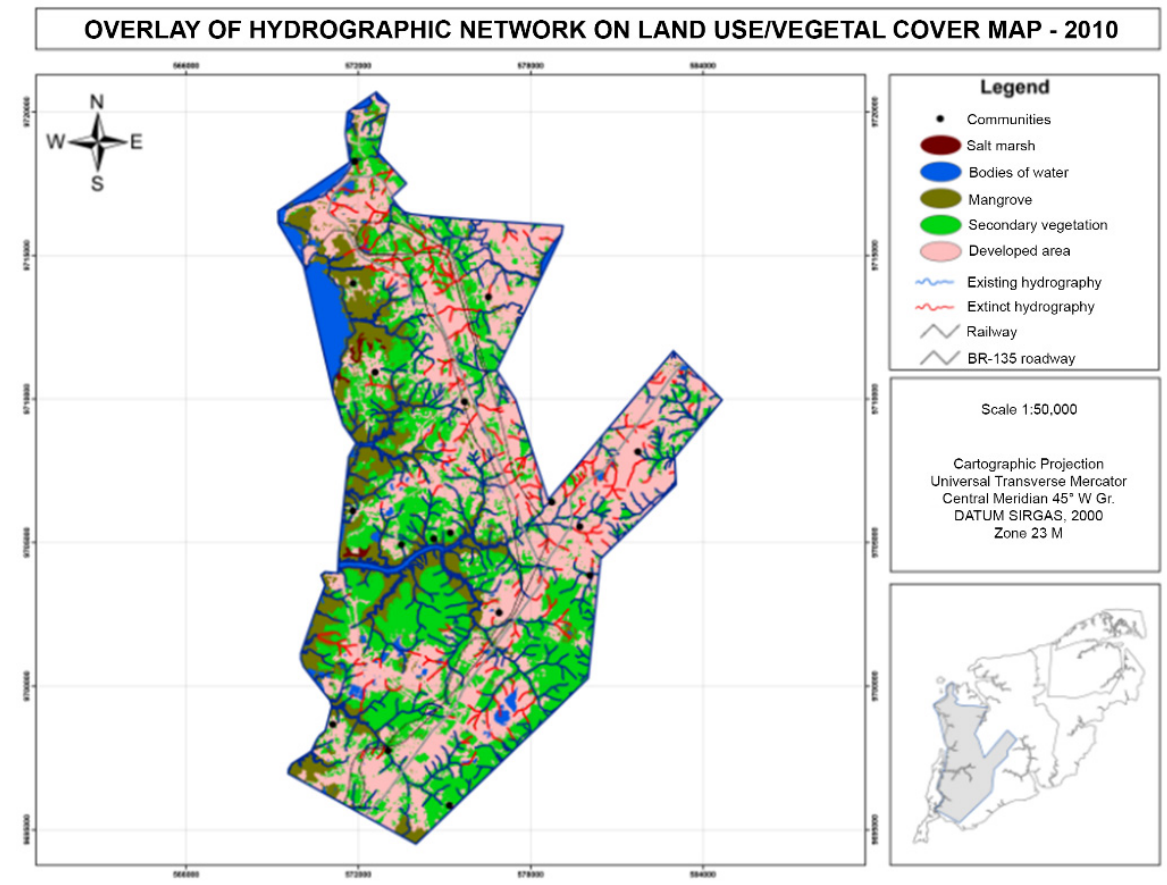

Figure 7. Overlay of hydrographic network on land use/vegetal cover map for 2010

The analysis of the maps reveals that the rivers and streams that once emptied at Boqueirão Beach in the northern portion of the district disappeared due to the implantation of the Ponta da Madeira Terminal in the 1980s. Other losses in this portion of the district also occurred due to the installation of VALE S/A and a thermoelectric plant at Itaqui Port. In the eastern portion, hydrographic losses occurred due to industrial expansion as well as disorganized land occupation due to the growth of the communities of Vila Maranhão, Gapara, Mata, Mata de Itapera and Ribeira. In the southern portion, hydrographic losses are found in the waste basin area of the ALUMAR factory and due to the disorganized expansion of the communities of Coqueiro and Pedrinhas, in the latter of which sand extraction enterprises have been installed.

The analysis of the hierarchy of the watercourses in the two years mapped demonstrates channels up the $5^{\text {th }}$ order (Figure 8). In 1980, $1^{\text {st }}$ order channels totaled $252.52 \mathrm{~mm}, 2^{\text {nd }}$ order channels totaled $92.97 \mathrm{~km}, 3^{\text {rd }}$ order channels totaled $51.01 \mathrm{~km}, 4^{\text {th }}$ order channels totaled $41.47 \mathrm{~km}$ and $5^{\text {th }}$ order channels totaled $15.86 \mathrm{~km}$. By 2012 , the hydrographic network had lost segments and, consequently, the extension of the watercourses had been reduced to $337.44 \mathrm{~km}$, with $1^{\text {st }}$ order channels totaling $187.32,2^{\text {nd }}$ order channels totaling $75.20 \mathrm{~km}, 3^{\text {rd }}$ order channels totaling $40.58 \mathrm{~km}, 4^{\text {th }}$ order channels totaling $20.83 \mathrm{~km}$ and $5^{\text {th }}$ order channels totaling $13.49 \mathrm{~km}$. 


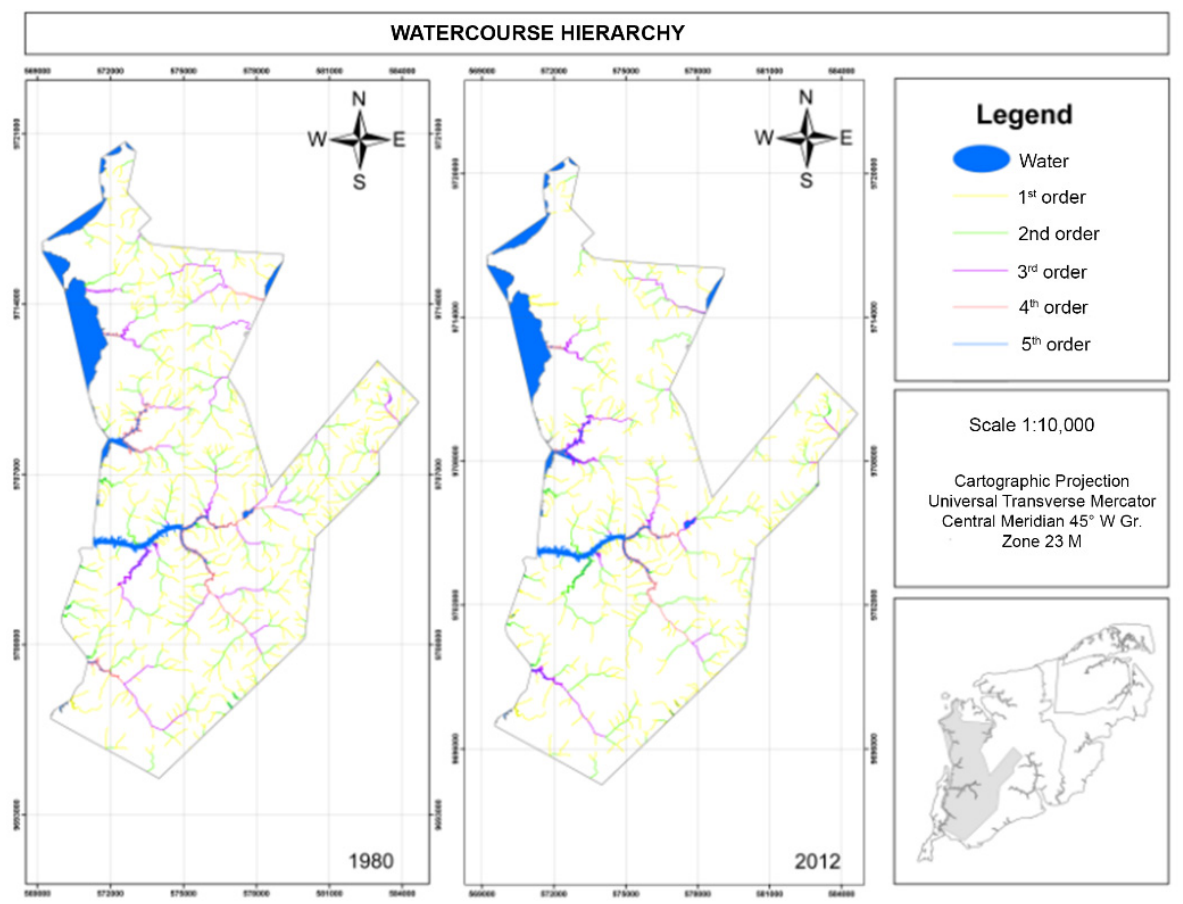

Figure 8. Spatiotemporal map of watercourse hierarchy in industrial district of São Luís

When designed ignoring a regional development plan, large projects are not expressed as endogenous social, political and economic forces. Thus, such projects can break down traditional economic and social relations, affecting the region in which they are implanted (Freitas and Oliveira, 2012). As Phelan et al. (2017) point out, the evaluation of social externalities is an important step towards understanding and responding to the changes induced by major resource projects and enhancing the outcomes for communities and society. The authors state that identifying and responding to internal and external factors that determine whether the benefits and costs of economic development are equitably distributed is central to supporting the sustainability needs of the community.

\section{Conclusion}

The present findings demonstrate the new outlay of the land in the industrial district of the city of São Luís (state of Maranhão, northeastern Brazil) and the environmental changes linked to processes of economic development and respective social problems on both spatial and temporal scales. The following paragraphs outline the main conclusions that can be drawn from the present study:

The socioeconomic conditions of the residents are precarious, as evidenced by the low income, literacy rate below the national average as well as inadequate sanitation, health and employment conditions. These factors demonstrate that the creation of the industrial district has not contributed to reducing poverty or social inequality. If public policies and measures are not adopted to improve the living conditions of the population through the creation of job opportunities, occupational training as well as physical and social infrastructure adequate to the new situation created by the industrial enterprises, there will always be the risk of increased social vulnerability and violence.

The degradation of vegetation constitutes the greatest consequence to the natural landscape having occurred in the region, with reductions of 4432.9 hectares of secondary vegetation in a span of 26 years (1984 to 2010) and 1437.7 hectares of mangrove vegetation in a span of 32 years (1980 to 2012).

Changes have occurred in the local hydrography, with a reduction in buffer zones alongside rivers and streams, corresponding to the disappearance of 1935.5 hectares of protection areas around springs and the loss of 142 initial points of the formation of perennial and intermittent watercourses. Such attributes are considered Permanent Preservation Areas by current legislation.

A reduction of $116.4 \mathrm{~km}$ occurred in the extension of watercourses. First order channels underwent the greatest 
degradation, with the loss of $65.2 \mathrm{~km}$ in a span of 32 years (1980 to 2012).

The creation of the industrial district of São Luís and associated enterprises has led to conflicts with other economic activities that have also existed in the surrounding areas, such as fishing, tourism and subsistence agriculture.

The expropriation of properties and relocation of populations have caused feelings of the loss of identity, the de-structuring of community living spaces and negative impacts on the production and subsistence of families. Such impacts have occurred in both an isolated fashion as well as in entire communities, especially in areas where rural communities or settlements predominate.

The present findings underscore the need for urgent measures to ensure local socioeconomic development as well as the protection of the remaining portions of the natural landscape in the region, especially with regard to Permanent Preservation Areas, which are legally protected environments and should therefore not be undergoing changes. The spatiotemporal mapping, field expeditions and data extracted from the literature contributed to the determination of the current situation of degradation of the natural landscape in the industrial district of São Luís resulting from the development of industrial activities, mineral extraction and disorganized land occupation. However, it is still possible to establish new forms of land use and achieve the environmental recovery of areas degraded by the activities of greatest impact in the area.

\section{Acknowledgements}

The authors thank the Fundação de Amparo à Pesquisa e ao Desenvolvimento Científico e Tecnológico do Maranhão (FAPEMA), by the financial support for the accomplishment of this work.

\section{References}

Bailey, K. D. (2008). Methods of Social Research (4th ed.). The Free Press. New York, NY: 592p.

BRASIL. (1980). Decreto $\mathrm{n}^{\circ} 1.813$, de 24 de novembro de 1980. Institui regime especial de incentivos para os empreendimentos integrantes do Programa Grande Carajás. Presidência da República. Casa Civil. Subchefia para assuntos jurídicos. Brasília, DF, 24 nov. 1980. Disponível em: http://www.planalto.gov.br/ccivil_03/Decreto-Lei/1965-1988/Del1813.htm. Acesso em: 13 de maio de 2014.

BRASIL. (2014). Lei ordinária no 13.005 de 25 de junho de 2014. Plano Nacional de Educação. Presidência da República. Casa Civil. Subchefia para assuntos jurídicos. Brasília.

Depietri, Y., Kallis, G., Baró, F., \& Cattaneo, C. (2016). The urban political ecology of ecosystem services: The case of Barcelona. Ecological Economics, 125, 83-100. https://doi.org/10.1016/j.ecolecon.2016.03.003

Freitas, B. V., \& Oliveira, E. L. (2012). Impactos socioeconômicos da construção do Complexo Portuário-Industrial do Açu sobre a população e o território de São João da Barra. Revista de Geografia PPGEO, 2(1), 1-10.

Gistelinck, F. (1988). Carajás: Usina e favelas. Gráfica Minerva LTDA. Taubaté.

Gonçalves, C. W. P. (2005). Amazônia, Amazônias. São Paulo. Contexto, 178p.

IBGE - Instituto Brasileiro de Geografia e Estatística. (2011). Base de informações do Censo Demográfico 2010: resultados do universo por setor censitário. Rio de Janeiro.

Johansson, E. L., \& Isgren, E. (2017). Local perceptions of land-use change: using participatory art to reveal direct and indirect socioenvironmental effects of land acquisitions in Kilombero Valley, Tanzania. Ecology and Society, 22(1), 3. https://doi.org/10.5751/ES-08986-220103

LANDSAT 5TM. São José dos Campos. Instituto Nacional de Pesquisas Espaciais, 1984-2010. Imagem de satélite. Canais 5,4,3 e composição colorida 5,4,3. Escala 1:100.000.

Nunes, E. M., \& Garcia, L. G. (2012). Sociedade e Natureza: conflito territorial de poluição industrial da bacia do rio Gramame-Mumbaba-PB. Revista Sociedade e Natureza, 24(2), 255-266. https://doi.org/10.1590/S1982-45132012000200007

Phelan, A., Dawes, L., Costanza, R., \& Kubiszewski, I. (2017). Evaluation of social externalities in regional communities affected by coal seam gas projects: A case study from Southeast Queensland. Ecological Economics, 131, 300-311. https://doi.org/10.1016/j.ecolecon.2016.09.010

Sant'Ana Júnior, H. A., \& Alves, E. J. P. (2010). Conflitos socioambientais no Maranhão: os povoados de Camboa dos Frades (São Luís-MA) e Salvaterra (Rosário-MA). In: GUIVANT, Julia S.; JACOBI, Pedro 
Roberto (Orgs.). Perspectivas ambientais: novos teóricos e novas agendas públicas. Coletânea da ANPPAS.

Sant'Ana Júnior, H. A., \& Silva, S. C. (2009). Grandes Projetos de Desenvolvimento, Conflito Socioambiental, Reserva Extrativista e o Povoado do Taim. Revista de Ciências Sociais, 40(1), 31-42.

Vieira, I. C. G, Jardim, A. G., \& Rocha, J. P. (Orgs.). (2015). Amazônia em tempo: estudos climáticos e socioambientais. Belém, Universidade Federal do Pará: Museu Paraense Emílio Goeldi: Embrapa Amazônia Oriental, 462 p.

\section{Copyrights}

Copyright for this article is retained by the author(s), with first publication rights granted to the journal.

This is an open-access article distributed under the terms and conditions of the Creative Commons Attribution license (http://creativecommons.org/licenses/by/4.0/). 